\title{
A new species of Farlowella (Siluriformes: Loricariidae) of the F. nattereri species-group from the rio Xingu basin, Mato Grosso, Brazil, with comments on Farlowella jauruensis, a poorly-known species from the upper rio Paraguai basin
}

\author{
Gustavo A. Ballen ${ }^{1,2}$, Murilo N. L. Pastana ${ }^{1}$ and Luiz A. W. Peixoto ${ }^{1}$
}

A new species of Farlowella is described from eighteen specimens collected in the upper rio Xingu basin, Mato Grosso State, Brazil. The new species is a member of the Farlowella nattereri species-group and can be distinguished from other members of the group, with exception of Farlowella jauruensis, by exhibiting a proportionally shorter snout. The new species is distinguished from $F$. jauruensis by differences on the cleithrum and plate morphology, by counts of pelvic and caudal-fin rays, and by the color pattern of the snout. The discovery of new lots of $F$. jauruensis, a species so far known only from the holotype, is also herein reported. This discovery represents a considerable expansion of the geographic distribution and of the number of known specimens of $F$. jauruensis.

Uma nova espécie de Farlowella é descrita de dezoito espécimes da bacia do alto rio Xingu, estado do Mato Grosso, Brasil. A nova espécie é membro do grupo de espécies da Farlowella nattereri, e é diagnosticada de outros membros deste grupo, com exceção de Farlowella jauruensis, por apresentar um focinho proporcionalmente mais curto. A nova espécie se diferencia de F. jauruensis por diferenças morfológicas do cleitro e de placas, pelas contagens de raios da nadadeira pélvica e caudal, e pelo padrão de colorido do focinho. A descoberta de novos lotes de F. jauruensis, uma espécie até então conhecida apenas pelo holótipo, também é aqui reportada. Esta descoberta representa uma expansão considerável da distribuição geográfica e do número de espécimes conhecidos de F. jauruensis.

Keywords: Amazon, Brazilian shield, Loricariinae, Neotropical fishes, Ostariophysi.

\section{Introduction}

Loricariinae is a subfamily of armored catfishes that currently comprises about 32 genera and near 240 valid species (Rodriguez et al., 2011; Eschmeyer \& Fong, 2016) recognized by exhibiting a long and depressed caudal peduncle and by the absence of an adipose fin (Covain \& Fisch-Muller, 2007). Among the Loricariinae, Farlowella Eigenmann \& Eigenmann is the second richest genus in the subfamily with 27 valid species (Ballen \& Mojica, 2014; Eschmeyer et al., 2016). The genus is recognized by its long and slender body and variably pronounced rostrum, and by its brown overall coloration with two longitudinal stripes extending from the tip of the rostrum to the caudal peduncle. The species allocated in this genus are broadly distributed in freshwater streams and rivers of the Amazon, Orinoco,
Maracaibo, Paraná and coastal drainages of the Guiana shield (Covain \& Fisch-Muller, 2007), being recently recorded for the Magdalena-Cauca system (Ballen \& Mojica, 2014).

The genus was revised by Retzer \& Page (1996) who proposed an intrageneric arrangement consisting of species groups. The taxonomy of these groups was based mainly on the number, shape, and location of dermal plates and odontodes. Recent investigations conducted on collection material of the Museu de Zoologia da Universidade de São Paulo (MZUSP) assigned to the genus Farlowella revealed an undescribed species from the rio Xingu basin, Mato Grosso State, Brazil. Also among the Farlowella specimens of MZUSP, some unidentified specimens of the genus were found to be Farlowella jauruensis Eigenmann \& Vance, a species known only from its type locality at rio Jauru, rio Paraguai basin.

${ }^{1}$ Museu de Zoologia da Universidade de São Paulo, Caixa Postal 42494, 04218-970 São Paulo, SP, Brazil. (GAB) gaballench@gmail.com (corresponding author), (MNLP)murilopastana@gmail.com, (LAWP) luizwp@yahoo.com.br

${ }^{2}$ Laboratorio de Ictiología, Departamento de Biología, Facultad de Ciencias, Pontificia Universidad Javeriana, Carrera 7 N 43-82, Bogotá, Colombia. 
The goal of this article is to provide a formal description of the new species of Farlowella from the Xingu basin and present the first records of $F$. jauruensis after its formal description performed by Eigenmann \& Vance (1917), representing a considerable expansion of the geographic distribution of the later species.

\section{Material and Methods}

Terminology, meristics and measurements follow Boeseman (1971, 1976), Retzer \& Page (1996), Schaefer (1997), and Paixão \& Toledo-Piza (2009); osteological terminology follows Geerinckx et al. (2007). Lateral plate series in Farlowella show variation in the fusion between the dorsomedian and median plate series, exhibiting four series when the plates are fused anteriorly, or five series when the anteriormost dorsomedian plates are free. In such cases the fusion occurs further posteriorly, near the vertical through the dorsal fin; posterior to dorsalfin base only three lateral series remain free (i.e., dorsal, dorsomedian + median+ventromedian, and ventral). Number of plates in each series is counted as presented in the Fig. 1: the dorsal, compound-median, and ventral series includes the longitudinal series of plates on the body, starting with the first plate posterior to the head limit and extending to the caudal-fin base. Dorsomedian, median, and ventromedian series include all the plates present in line anterior to a fusion of plates (Fig. 1). Abdominal plates are those between pectoral-fin and pelvic-fin insertion in the ventral plate series, midabdominal plates are a series of minute plates located in between the two abdominal series (Retzer \& Page, 1996: fig. 6, a-f), and the coalescent series includes plates from the point of fusion of median and ventromedian series to the caudal-fin base.

Meristics are reported followed by their frequencies in parentheses with an asterisk indicating the count of the holotype. Measurements were taken with a digital caliper under a stereoscope. Standard length (SL) is given in millimeters $(\mathrm{mm})$, and morphometric data are reported as percentage of SL, or head length for head subunits. Museum acronyms follow Sabaj-Pérez (2014). Species groups herein discussed follow Retzer \& Page (1996), Retzer (2006), and Ballen \& Mojica (2014). Statistical summaries were prepared with the program R v. 2.10.0 (R Development Core Team, 2012), available at http://www.r-project.org. The code and data used to generate the Table 1 are available at https://github.com/gaballench/FarlowellaTables under the appropriate folder (i.e., Fgianetii). Given that some works on the taxonomy of Farlowella have reported morphometric characters in the form of ratios instead of the percentages (contra the standard practice in taxonomy), herein we provide the tables in percentages and a script and table in ratio form for facilitating comparisons whenever necessary; such materials are also available in the github repository.

\section{Farlowella gianetii, new species}

urn:1sid:zoobank.org:act:D0F 55C0E-2372-415D-A1DE6DC532934BA2

\section{Figs. 1-2}

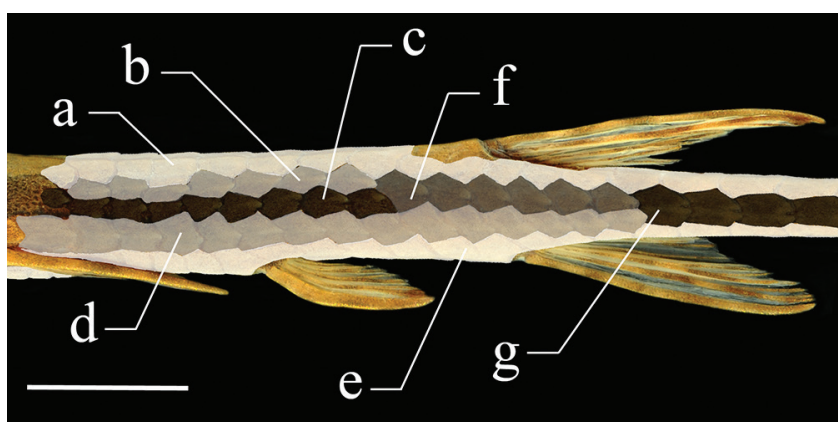

Fig. 1. Lateral plate series in Farlowella gianetii (holotype, MZUSP 95564, $115.6 \mathrm{~mm} \mathrm{SL}$ ). Each color represents individual series or fusions referred in the text. Plate series as follows: a) dorsal, b) dorsomedian, c) median, d) ventromedian, e) ventral, f) dorsomedian+median, g) coalescent series (dorsomedian+median+ventromedian). Scale bar: $1 \mathrm{~cm}$.

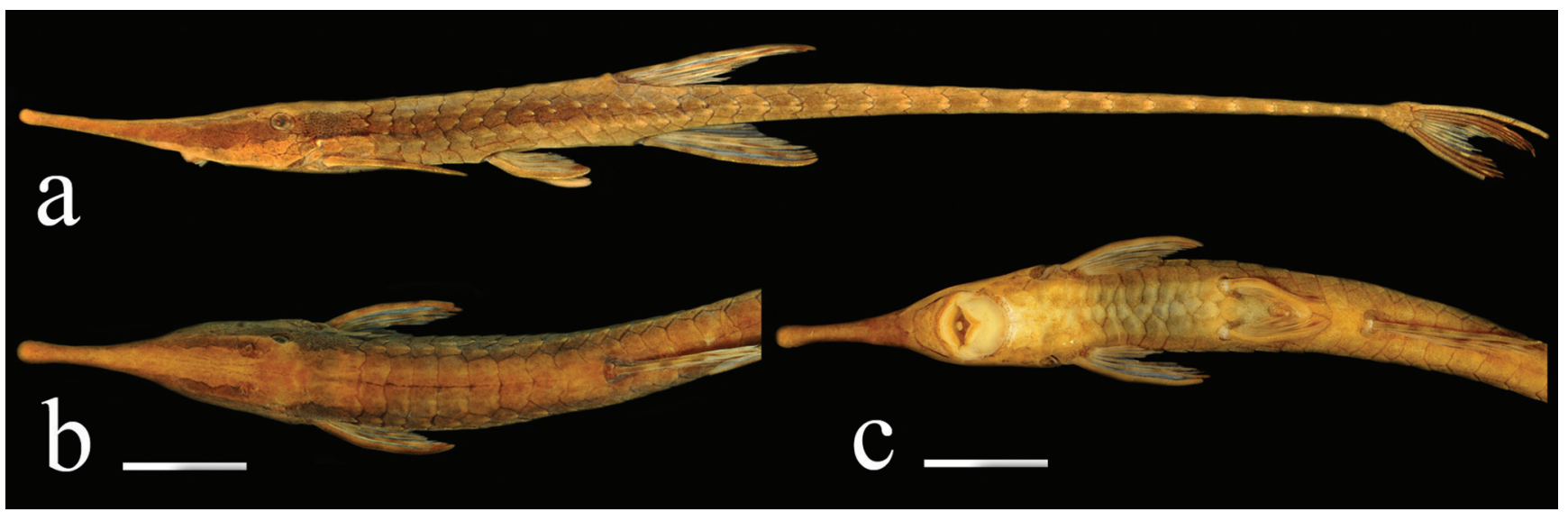

Fig. 2. Farlowella gianetii, Brazil: Mato Grosso, Campinápolis, rio Couto do Magalhães. MZUSP 95564 holotype, 115.6 $\mathrm{mm} \mathrm{SL}$, a) lateral, b) dorsal, and c) ventral views. Scale bar: $1 \mathrm{~cm}$. 
Holotype. MZUSP 95564, 115.6 mm SL, Brazil, Mato Grosso, Campinápolis, rio Couto de Magalhães, rio Xingu basin, $13^{\circ} 50^{\prime} 17^{\prime \prime S} 53^{\circ} 03^{\prime} 53^{\prime \prime}$, F. Lima, C. Moreira, F. Machado \& A. Ribeiro, 6 Oct 2007.

Paratypes. Brazil, Mato Grosso: MZUSP 120420, 7, 63.4$103.4 \mathrm{~mm} \mathrm{SL}$, same data as holotype; MZUSP 87010, 1, $86.0 \mathrm{~mm} \mathrm{SL}$, Gaúcha do Norte, rio Culuene, rio Xingu basin, $13^{\circ} 30^{\prime} 52^{\prime \prime}$ S $53^{\circ} 05^{\prime} 34^{\prime \prime} \mathrm{W}$, O. Oyakawa, J. Birindelli \& C. Nolasco, 19 Oct 2004; MZUSP 98187, 1, 61.7 mm SL,

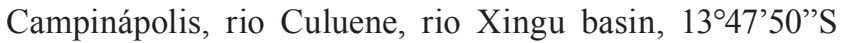
$53^{\circ} 14^{\prime} 46^{\prime \prime W}$, F. Lima, F. Machado, A. Ribeiro, C. Leite \& C. Moreira, 2 Oct 2007; MZUSP 97022, 4, 95.4-121.0 mm SL, Campinápolis, rio Couto de Magalhães, rio Xingu basin, $13^{\circ} 48^{\prime} 02^{\prime \prime S} 53^{\circ} 03^{\prime} 43^{\prime}$ 'W, F. Lima, A. Ribeiro, C. Leite \& L. Moraes, 10 Oct 2007; MZUSP 99065, 2, 82.7-90.3 mm SL, Campinápolis, rio Couto de Magalhães, rio Xingu basin, 135'16"S 531'27'W, F. Lima, A. Ribeiro, C. Leite \& L. Moraes, 12 Oct 2007; MZUSP 97056, 2, 79.1-108.5 mm SL, Campinápolis, córrego Água Fria, rio Couto de Magalhães,

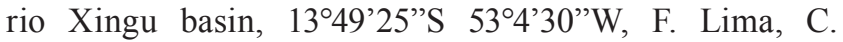
Moreira, F. Machado, A. Ribeiro \& C. Leite, 6 Oct 2007.

Diagnosis. Farlowella gianetii differs from most congeners, except Farlowella altocorpus Retzer, Farlowella gracilis Regan, Farlowella hasemani Eigenmann \& Vance, Farlowella isbruckeri Retzer \& Page, Farlowella jauruensis, Farlowella nattereri Steindachner, and Farlowella odontotumulus Retzer \& Page, by the presence of five lateral plate series on body (vs. four in Farlowella acus (Kner), Farlowella amazona (Günther), Farlowella colombiensis Retzer \& Page, Farlowella curtirostra Myers, Farlowella hahni Meiken, Farlowella henriquei Miranda-Ribeiro, Farlowella knerii (Steindachner), Farlowella mariaelenae Martín-Salazar, Farlowella martini Fernández-Yepez, Farlowella oxyrrhyncha (Kner), Farlowella paraguayensis Retzer \& Page, Farlowella platorhynchus Retzer \& Page, Farlowella reticulata Boeseman, Farlowella rugosa Boeseman, Farlowella schreittmuelleri Ahl, Farlowella smithi Fowler, Farlowella taphorni Retzer \& Page, Farlowella venezuelensis MartínSalazar, Farlowella vittata Myers, and Farlowella yarigui Ballen \& Mojica). It differs from F. altocorpus by presenting a body width at dorsal origin to SL 4.4-5.8\% (vs. body width at dorsal origin to SL $6.4-8.1 \%$ in $F$. altocorpus) and body depth. to SL $4.5-5.4 \%$ (vs. body depth to SL $5.4-6.5 \%$ in $F$. altocorpus). It can be differentiated from F. gracilis, $F$. hasemani, F. isbruckeri, F. nattereri, and F. odontotumulus by presenting a proportionally shorter snout (snout-mouth length to HL < 0.5) ( $v s$. longer snout, with snout-mouth length to $\mathrm{HL}>=0.5$ in the latter species). The new species can be distinguished from $F$. jauruensis by the color pattern of the snout consisting of dark pigment only laterally ( $v s$. snout completely dark) (Fig. 3), by the number of pelvic-fin rays, i,4 ( $v s . i, 5)$, by the number of caudal-fin rays, i,10,i ( $v s$. $\mathrm{i}, 11, \mathrm{i}$ or $\mathrm{i}, 12, \mathrm{i})$, by presenting an upper portion of cleithrum robust sensu Retzer \& Page (1996, fig. 5) (vs. upper portion of cleithrum narrow), lower cleithrum thin sensu Retzer \& Page (1996, fig. 5) (vs. lower cleithrum well-exposed), and median lateral plates rectangular and low (vs. median lateral plates diamond-shaped and deep).

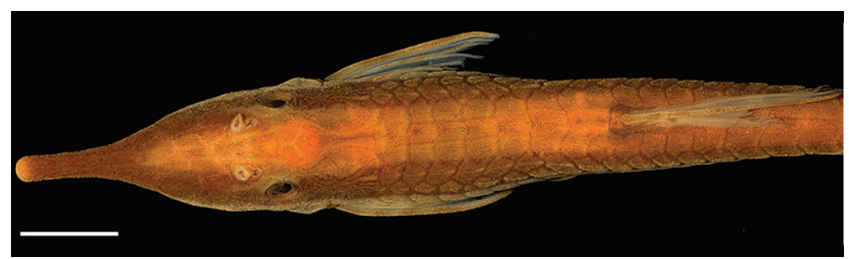

Fig. 3. Dorsal view of anterior portion of Farlowella jauruensis, MZUSP 59485, 77.6 mm SL. Note the distinctive coloration on snout. Scale bar: $5 \mathrm{~mm}$.

Description. Morphometric data for the holotype and paratypes presented in Table 1. Body very elongate, slender, dorsoventrally depressed. Greatest body depth at region of pelvic-fin insertion; greatest body width at region of pelvic-fin insertion. Overall shape elongate and cylindrical. Head slightly depressed, body cylindrical, tail depressed. Dorsal profile from tip of snout to level of nares slightly concave, nearly straight from that point to dorsal-fin insertion; straight from dorsal-fin terminus to anteriormost dorsal caudal-fin procurrent ray. Ventral profile obliquely straight from tip of snout to pectoral girdle, straight from that point to anal-fin insertion; straight from last anal-fin ray insertions to anteriormost ventral caudal-fin procurrent ray. Body completely covered with plates except for tip of snout, gular region, and oval region surrounding urogenital aperture.

Lateral margins of head paralleled from tip of snout to midpoint to vertical through nares in dorsal view, concave at this point, and nearly straight from such landmark to opercular region. Snout short, papillae absent. Preorbital ridge present. Anterior and posterior nares of similar size, dermal flap separating openings. Eyes lateral, not visible in ventral view, visible in dorsal view. Eyes not raised above head surface; iris operculum present. Sixth infraorbital evident. Dorsal surface of head with longitudinal keel on parieto-supraoccipital bone; compound pterotic ornamented with reticulate pattern of ridges and pits. Mouth ovoid, lower lip larger than upper lip; ventral surface covered by wide oval papillae on upper lip and round papillae on lower lip; round papillae decreasing in size from oral aperture to lip margin; lip margin papillose. Few platelets covering dorsal surface of upper lip. Each premaxilla with 19(1), 20(3), 21(3), 22(2), 23(2), 24(4), $25(1), 27^{*}(1)$, or $28(1)$ bicuspid teeth, each dentary with 18(3), 19(6), 20(4), 21(1), 22(3) or 23*(1) bicuspid teeth; premaxilla wider than dentary. Buccal papilla present, with papillose surface. Ventral surface of head completely covered by platelets without a particular arrangement. Maxillary barbel present and projecting slightly from mouth margin. 
Table 1. Morphometric data for holotype and paratypes of Farlowella gianetii, new species ( $\mathrm{N}=18)$.

\begin{tabular}{|c|c|c|c|c|c|c|c|}
\hline \multirow[b]{2}{*}{ Measurement } & \multicolumn{4}{|c|}{ Farlowella gianetii } & \multicolumn{3}{|c|}{ Farlowella jauruensis } \\
\hline & Holotype & Mean & SD & Range & Mean & $\mathrm{SD}$ & Range \\
\hline Standard length (SL) & 115.6 & 89.1 & 19.4 & $61.7-121$ & 69.4 & 13.1 & $56.9-83.5$ \\
\hline \multicolumn{8}{|c|}{ Percentages of SL } \\
\hline Head length (HL) & 22.1 & 22.5 & 1 & $20.3-24.6$ & 23.4 & 1.1 & $21.7-24.2$ \\
\hline Body depth at dorsal origin & 5.3 & 5 & 0.2 & $4.5-5.4$ & 5 & 0.5 & $4.5-5.4$ \\
\hline Body width at dorsal origin & 5.7 & 5.4 & 0.4 & $4.4-5.8$ & 5.5 & 0.7 & $4.8-6.3$ \\
\hline Body width at anal origin & 5.6 & 5.3 & 0.5 & $3.8-6$ & 5.4 & 0.7 & $4.9-6.3$ \\
\hline Predorsal length & 42.8 & 42.6 & 1.4 & $40.5-46.2$ & 43.9 & 2.5 & $40.9-46.4$ \\
\hline Postorsal length & 53.1 & 52.4 & 1.7 & $48.3-54.5$ & 52.1 & 1.9 & $50.7-54.8$ \\
\hline Postanal length & 51.1 & 52 & 0.9 & $50-53.5$ & 50.6 & 0.9 & $49.7-51.4$ \\
\hline Caudal peduncle depth & 1.2 & 1.2 & 0.1 & $1-1.5$ & 1.4 & 0.2 & $1.2-1.5$ \\
\hline Dorsal-spine length & 14.7 & 13.6 & 0.7 & $12-14.9$ & 14.5 & 1.1 & $13.2-15.8$ \\
\hline Pectoral-spine length & 10.9 & 10.8 & 0.6 & $9.8-12.6$ & 11.5 & 1.8 & $9.7-13.9$ \\
\hline Pelvic-spine length & 7.3 & 7.2 & 0.4 & $6.4-7.8$ & 7.1 & 0.6 & $6.6-7.8$ \\
\hline Anal-spine length & 12.8 & 12.6 & 1.2 & $8.3-14$ & 13.5 & 0.9 & $12.6-14.6$ \\
\hline \multicolumn{8}{|c|}{ Percentages of HL } \\
\hline Snout length & 18.3 & 18.8 & 1 & $16.6-20.5$ & 18.5 & 0.8 & $17.3-19$ \\
\hline Snout-mouth length & 10.8 & 11.2 & 0.9 & $9.6-12.7$ & 10.1 & 0.7 & $9.1-10.8$ \\
\hline Eye diameter & 7.3 & 8.6 & 1 & $7.1-10.8$ & 10.8 & 0.7 & $10-11.5$ \\
\hline Interorbital width & 19.4 & 19.7 & 1.1 & $17.7-22$ & 21.2 & 1.7 & $19.7-23.2$ \\
\hline Head width & 34.2 & 33 & 1.8 & $29.9-36.6$ & 33.4 & 5.2 & $28.1-39.7$ \\
\hline Head depth & 23 & 22.3 & 1.5 & $18.8-24$ & 23.3 & 2.4 & $21.1-26.7$ \\
\hline \multicolumn{8}{|c|}{ Proportion characters sensu Retzer \& Page (1996) } \\
\hline Snout-mouth length / pectoral-spine lenth & 99.1 & 103.8 & 10.3 & $84.8-124.8$ & 89.5 & 16.8 & $65.4-104$ \\
\hline Snout-mouth length / HL & 48.7 & 49.5 & 2.7 & $46-54.4$ & 43 & 1.6 & $41.9-45.3$ \\
\hline HL / Snout-mouth length & 205.2 & 202.5 & 10.8 & $183.8-217.6$ & 232.6 & 8.5 & $220.6-238.6$ \\
\hline Body depth / pelvic-spine length & 72 & 68.8 & 3 & $62.6-74.3$ & 70.5 & 7.3 & $63.4-80.7$ \\
\hline Pectoral spine length / snout-mouth length & 100.9 & 97.3 & 9.8 & $80.1-118$ & 115.3 & 25.5 & $96.2-152.8$ \\
\hline Snout-mouth length / interorbital width & 251.2 & 251.9 & 24.2 & $208.8-295.3$ & 203.8 & 15.8 & $181-215.9$ \\
\hline Body width / snout-mouth length & 52.5 & 48.8 & 5.4 & $40.1-60$ & 55.2 & 10.2 & $46.8-69.4$ \\
\hline
\end{tabular}

Five lateral plate rows on body, with 31(1), 32(10) or $33^{*}(7)$ plates present on the medial line, and 13(8), 14(6), $15^{*}(3)$ or 16(1) median plates before the coalescent series. Dorsal plates distributed in $8(15)$ or $9 *(3)$ predorsal plates, and $19(2), 20 *(10)$ or $21(6)$ postdorsal plates. Abdomen flat, covered with two lateral complete rows with 5(2), 6(4), $7(9), 8(1)$ or $9^{*}(2)$ plates, and one midabdominal complete row with 6(1), 7(9), 8(2) or $9 *(6)$ plates. Lateral abdominal plates angled and delimiting abdomen laterally. Anal plate inverted Y-shaped with anterior margin straight. Postanal plates $19(3), 20 *(9)$ or $21(6)$.

Pectoral fin i,5(1) or i,6*(17), with distal margin straight, leading ray longest, twice as thick as branched rays; pelvic fin i, $5^{*}(18)$ [two specimens with i,6 in one side of the body], with posterior margin slightly curved; dorsal fin $\mathrm{i}, 6^{*}(18)$, with posterior margin straight, triangular in overall shape. Anal fin i, $5^{*}(18)$, similar in size and shape to dorsal fin. Caudal fin i,10,i*(18), emarginated, with dorsal and ventral lobes similar in size; filaments present on both dorsal and ventral principal caudal-fin ray.
Coloration in alcohol. Head, dorsum, and caudal peduncle light brown; sides of head and body with longitudinal dark brown stripe continuous from tip of snout to fusion of median and ventromedian plate rows; ventral portions of head, body, and caudal peduncle light brown from snout to base of caudal fin; some individuals show abdomen lighter than ventral portions of head, body, and caudal peduncle. Head with dark pigment delimiting plates in dorsal and lateral views; longitudinal dark brown stripe present from parieto-supraoccipital to dorsal-fin insertion; light area more evident from tip of snout to posterior margin of nares, continuing along dorsum until caudal fin. Dorsal, pectoral, pelvic, and anal fins with hyaline membranes and black spots on rays poorly arranged in bars, more evident in dorsal and anal fin. Caudal fin with overall dark brown-black coloration on both membranes and rays; area free of pigment present posteriorly at level of caudal emargination; variable clear ocelli present on dorsal and ventral lobes toward margins of lobes. 
Distribution. Farlowella gianetii is known from the upper rio Xingu basin, from rio Couto de Magalhães, rio Culuene, and from smaller tributaries of the upper rio Xingu, Mato Grosso State, Brazil (Fig. 4).

Etymology. The specific epithet, gianetii (a patronym in genitive case), is after Dr. Michel Donato Gianeti, collection manager at the ichthyological collection of the Museu de Zoologia da Universidade de São Paulo, in recognition to all the kind assistance provided both during visits to the ichthyological collection of the MZUSP and through loan/data request management.

Remarks. Position of the new species in the genus. The new species is allocated to the Farlowella nattereri group of Retzer \& Page (1996) because it exhibits the following characteristics: five lateral plates on the anterior portion of the body, three abdominal plate series, and diamondshaped median plates. Among the species of this group, the new species is most similar to $F$. jauruensis, sharing with that species a short snout and the apparent lack of breeding odontodes on body. The species is known only from around its type locality in the upper portion of rio Xingu basin.
Comments on some species of the Farlowella nattereri species group. The last revisionary work on Farlowella suggests that $F$. jauruensis is a valid species from the rio Paraguai basin, Brazil. Until the present contribution, this species was known only from the holotype, collected by John D. Haseman in 1909. This species is characteristic by its relatively short snout in contrast to species of the $F$. nattereri species group, that present a long snout (Retzer \& Page, 1996). During the revision of comparative material, several unidentified specimens of short-snouted Farlowella species collected in the rio Paraguai basin were found at the MZUSP ichthyological collection. Analysis of these specimens revealed that they match the diagnostic characters reported by Retzer \& Page (1996). Farlowella jauruensis is distinctive because of its dark snout, characteristic that was overlooked both by Eigenmann \& Vance (1917) and Retzer \& Page (1996), and that further diagnoses this species from closely relatives of the $F$. nattereri species group. The discovery of this important material at the MZUSP collection extends both the number of known specimens and distribution range of this poorly-known Farlowella species. This species seems to be restricted to the upper rio Paraguai basin.

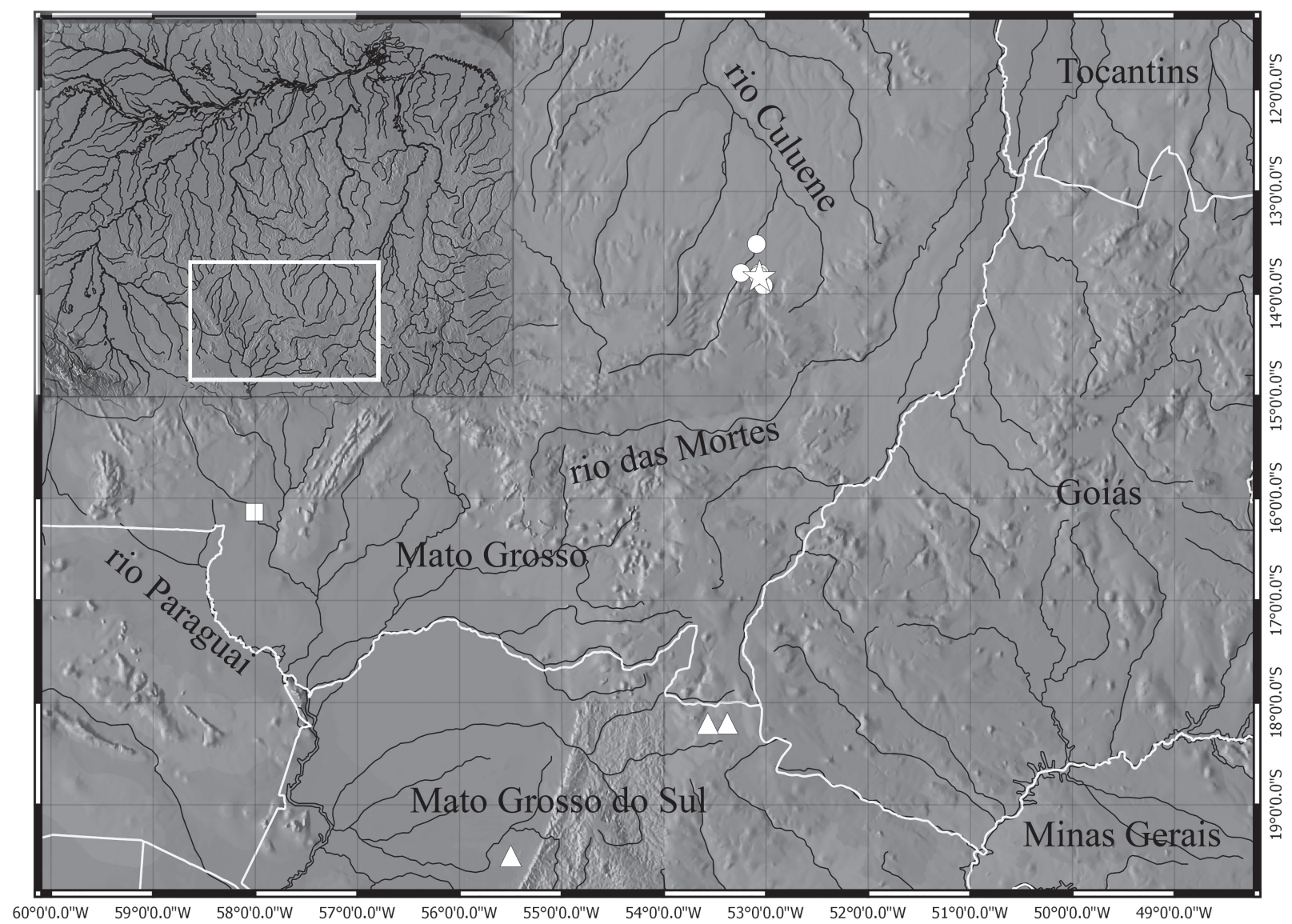

Fig. 4. Distribution of Farlowella gianetii in the upper rio Xingu basin and Farlowella jauruensis in the upper rio Paraguai basin. Symbols represent the type-locality of $F$. gianetii (star) and $F$. jauruensis (square), along with additional specimens of $F$. gianetii (spots) and $F$. jauruensis (triangles). Major rivers are indicated in the map. 
The type-locality of $F$. jauruensis has been matter of some confusion from the original description to our current understanding of its location. Eigenmann \& Vance (1917) reported it in the original description of the species as "Jaura, June 2, 1909, Haseman." Subsequently Retzer \& Page (1996) specified such locality as "Brazil, Mato Grosso do Sul State, Jaura [Jauru], probably the rio Jauru, 2 June 1909." However, Haseman \& Eigenmann (1911) reported explicitly such locality as "Campos Alegre, rio Jauru, into rio Paraguai... [t]wenty-eight miles above mouth of rio Jauru and about thirty southwest of São Luiz de Cáceres... [j]une 2, 1909." Therefore such locality is not in the state of Mato Grosso do Sul but in the adjacent state of Mato Grosso, in the city of Cáceres, on the eastern bank of the rio Paraguai. The rio Jauru is located southwest of the city and empties into the rio Paraguai on the western bank. It is intriguing why Eigenmann \&Vance (1917) did not use the complete locality information available in Haseman \& Eigenmann (1911) but a shorter version or even a mention of that reference, but this is the apparent reason for the confusing location of the rio Jauru in a different state by Retzer \& Page (1996). Also, it is noteworthy that the separation between Mato Grosso and Mato Grosso do Sul states dates back to 1977 (Queiroz, 2006) and therefore confusion between states is also a possible explanation for this misplaced type locality. Estimated coordinates based on the distance between Cáceres and the collection locality reported by Haseman are $16^{\circ} 08^{\prime} 14.5^{\prime} \mathrm{S} 58^{\circ} 00^{\prime} 37.5^{\prime} \mathrm{W}$ in the current Campo Alegre settlement, municipality of Cáceres (Fig. 4). This clarification is pertinent since there is another river called Jauru, but in the state of Mato Grosso do Sul, near Coxim (1843'24.1's 54²9'35.0'W), ca. $470 \mathrm{~km}$ in linear distance from the rio Jauru in the state of Mato Grosso.

Additional records for $F$. jauruensis were collected in the córrego Engano (ribeirão do Engano), rio Taboco and rio Taquari, all three localities in the state of Mato Grosso do Sul, extending the known distribution of this species into the states of Mato Grosso (type locality) and Mato Grosso do Sul (remaining known records), rio Paraguai basin, Brazil (Fig. 4).

Retzer \& Page (1996) described F. isbruckeri from the states of Mato Grosso and Mato Grosso do Sul in Brazil using material currently housed at the Museu de Zoologia da Universidade de São Paulo as well as a paratype at the Illinois Natural History Survey. They report the holotype to be "MZUSP 37641, 131.1 mm SL, male, Brazil, Mato Grosso State, small river on highway from Cuiabá to Porto Velho, approximately $32 \mathrm{~km}$ from Lacerda." During the course of the present study we tried to locate such lot in the MZUSP fish collection and found it to contain 12 specimens of different species (i.e., a juvenile $F$. isbruckeri and several adults and juveniles of F. paraguayensis; G. A. Ballen, pers. obs.). However, none of the specimens matched the characteristics of the holotype reported in the original description, and the only specimen matching the reported SL was in fact an adult of $F$. paraguayesis lacking sexual dimorphic characteristics. Therefore we conclude that the holotype is absent from such specimen lot and suggest it to be lost after extensive review of material of the genus Farlowella in the MZUSP fish collection. Following the original description it is unlikely that the real holotype of $F$. isbruckeri is in fact the specimen matching the SL as the differences between $F$. isbruckeri and $F$. paraguayensis are very notorious, and therefore we disfavor an explanation of conspecificity between these species.

Comparative material. Brazil: Farlowella amazona: MZUSP 24223, 1, $128.8 \mathrm{~mm}$ SL, Pará, igarapé Urubu, rio Tocantins basin, near Posto de Trocará. MZUSP 117599, 2, 49.4-111.8 mm SL, Amazonas, rio Juma, rio Aripuanã basin, near Apuí. Farlowella henriquei: MZUSP 2159, holotype, $166.2 \mathrm{~mm}$ SL, Goiás, Santa Rita das Antas, rio Vermelho, afluente do rio Araguaia, rio Tocantins basin. MZUSP 114179, 1, $81.1 \mathrm{~mm} \mathrm{SL}$, Tocantins, rio Palmas, rio Tocantins basin. MZUSP 114224, 2, 94.4-102.2 mm SL, Tocantins, córrego Cocal, rio Tocantins basin. MZUSP 4892, 5, 121.5-153.4 mm SL, Goias, rio Araguaia, rio Tocantins basin. Farlowella jauruensis: MZUSP 59457, 2, 56.9-59.6 mm SL, Mato Grosso do Sul, Aquidauana, rio Taboco, rio Paraguai basin. MZUSP 59485, 1, 77.5 mm SL, Mato Grosso do Sul, Coxim, Córrego do Engano, rio Paraguai basin. MZUSP 115560, 1, 83.4 mm SL, Mato Grosso do Sul, Alcinópolis, rio Taquari, rio Paraguai basin. Farlowella nattereri: MZUSP 74451, 1, 199.2 mm SL, lagoa junto ao canal do lago Janauacá, margem direita do rio Solimões. MZUSP 23276, 10, 82.9-157.1 mm SL, Coari, Ilha Sorubim. MZUSP 57862, 3, 92.8-103.1 mm $\mathrm{SL}$, Amazonas, rio Amazonas, $14 \mathrm{~km}$ abaixo do rio Madeira. MZUSP 56464, 1, $119.3 \mathrm{~mm} \mathrm{SL}, 15.6$ km. Amazonas, abaixo do rio Japurá. MZUSP 57865, 1, 102.9 mm SL, rio Amazonas, 60 mi. abaixo do rio Negro. Farlowella oxyrrhyncha: MZUSP 52119, 13, 55.7-125.6 mm SL, Tocantins, Araguaçú, rio Água Fria, rio Tocantins basin. MZUSP 92316, 1, $166.4 \mathrm{~mm}$ SL, Amazonas, São José, rio Tiquié, rio Negro basin. Farlowella paraguayensis: MZUSP 47243, paratypes, 123.6-134.8 mm SL, Mato Grosso, Pontes e Lacerda, riacho na rodovia Cuiabá-Porto Velho, rio Madeira basin. MZUSP 59733, 1, 89.2 mm SL, Mato Grosso do Sul, Alcinópolis, córrego da Furna, riacho Água Clara, rio Taquari basin. MZUSP 115601, 9, 65.5-104.8 mm SL, Mato Grosso do Sul, Alcinópolis, Fazenda Taquarizinho, rio Taquari, rio Paraguai basin. MZUSP120421, 5, 46.5-101.2 mm SL, Mato Grosso do Sul, Alcinópolis, rio Taquari, rio Paraguai basin. Farlowella schreitmuelleri: MZUSP 101583, 2, 89.3-129.9 mm SL, Amapá, Laranjal do Jari, rio Iratapuru, rio Amazonas basin. MZUSP 88706, 2, 75.2-77.9 9 mm SL, Amazonas, Rio Preto da Eva, rio Amazonas basin. Farlowella smithi: MZUSP 92220, 1, 219.4 mm SL, Amazonas, porto da comunidade de Pirarara Poço, rio Tiquié, rio Amazonas basin. MZUSP 92543, 1, $205.9 \mathrm{~mm}$ SL, igarapé Castanha próximo à foz, rio Tiquié, rio Amazonas basin. Venezuela: Farlowella acus: MZUSP 147, 2 , 109.5-123.3 mm SL, Valencia. 


\section{Acknowledgements}

This paper benefited from suggestions by Osvaldo Oyakawa. We are grateful to Michel Gianeti and Osvaldo Oyakawa for curatorial assistance. A specimen of Farlowella jauruensis (MZUSP 115560) was collected during an expedition of the South American Characiformes Inventory project, sponsored by FAPESP (\#2011/502827). The authors were funded through doctoral and BEPE internship grants by FAPESP (2014/11558-5 and 2016/02253-1 to GAB; 2013/09926-3 and 2015/24709-4 to LAWP) and CAPES (MNLP).

\section{References}

Ballen, G. A. \& J. I. Mojica. 2014. A new trans-Andean stick catfish of the genus Farlowella Eigenmann \& Eigenmann, 1889 (Siluriformes: Loricariidae) with the first record of the genus for the río Magdalena Basin in Colombia. Zootaxa, 3765: 134-142.

Boeseman, M. 1971. The "comb-toothed" Loricariinae of Surinam, with reflections on the phylogenetic tendencies within the family Loricariidae (Siluriformes, Siluroidei). Zoologische Verhandelingen, 116: 3-64.

Boeseman, M. 1976. A short review of the Surinam Loricariinae; with additional information on Surinam Harttiinae, including the description of a new species (Loricariidae, Siluriformes). Zoologische Mededelingen, 50: 153-185.

Covain, R. \& S. Fisch-Muller. 2007. The genera of the Neotropical armored catfish subfamily Loricariinae (Siluriformes: Loricariidae): a practical key and synopsis. Zootaxa, 1462: $1-40$.

Eigenmann, C. H. \& L. Vance. 1917. Some species of Farlowella. Annals of the Carnegie Museum, 11: 297-303.

Eschmeyer, W. N. \& J. D. Fong. 2016. Species by family/ subfamily. Available from: http://researcharchive.calacademy. org/research/ichthyology/catalog/SpeciesByFamily.asp/ (Date of access - 15 January 2016).

Eschmeyer, W. N, R. Fricke, \& van der Laan. 2016. Catalog of fishes: genera, species, references. Avaliable from: (http:// researcharchive.calacademy.org/research/ichthyology/ catalog/fishcatmain.asp/ (Date of access - 15 January 2016).

Geerinckx, T., M. Brunain, A. Herrel, P. Aerts, \& D. Adriaens. 2007. A head with a suckermouth: a functional morphological study of the head of the suckermouth armoured catfish Ancistrus cf. triradiatus (Loricariidae, Siluriformes). Belgian Journal of Zoology, 137: 47-66.
Haseman, J. D. \& C. H. Eigenmann. 1911. A brief report upon the expedition of the Carnegie Museum to central South America. Together with a list of localities at which Mr. Haseman collected. Annals of the Carnegie Museum, 7: 287-314.

Paixão, A. C. \& M. Toledo-Piza. 2009. Systematics of Lamontichthys Miranda-Ribeiro (Siluriformes: Loricariidae), with the description of two new species. Neotropical Ichthyology, 7: 519-568.

Queiroz, P. R. C. 2006. Mato Grosso/Mato Grosso do Sul: Divisionismo e identidades (um breve ensaio). Diálogos, 10: 149-184.

R Core Development Team. 2012. R: A language and environment for statistical computing (v. 2.10.0) [Software]. R Foundation for Statistical Computing, Viena. Available from: http:// www.r-project.org/ (Date of access - 15 January 2016).

Retzer, M. E. 2006. A new species of Farlowella Eigenmann and Eigenmann (Siluriformes: Loricariidae), a stickcatfish from Bolivia. Zootaxa, 1282: 59-68.

Retzer, M. E. \& L. M. Page. 1996. Systematics of the stick catfishes, Farlowella Eigenmann \& Eigenmann (Pisces, Loricariidae). Proceedings of the Academy of Natural Sciences of Philadelphia, 147: 33-88.

Rodriguez, M. S., H. Ortega \& R. Covain. 2011. Intergeneric phylogenetic relationships in catfishes of the Loricariinae (Siluriformes: Loricariidae), with the description of Fonchiiloricaria nanodon: a new genus and species from Peru. Journal of Fish Biology, 79: 875-895.

Sabaj-Perez, M. H.. 2014. Standard symbolic codes for institutional resource collections in herpetology and ichthyology: an Online Reference. Version 5.0 (22 September 2014). American Society of Ichthyologists and Herpetologists, Washington, DC. Available from: http://www.asih.org/resources/ standard-symbolic-codes-institutional-resource-collectionsherpetology-ichthyology (Date of access 15 January 2016).

Schaefer, S. A. 1997. The Neotropical cascudinhos: systematics and biogeography of the Otocinclus catfishes (Siluriformes: Loricariidae). Proceedings of the Academy of Natural Sciences of Philadelphia, 148: 1-120.

Submitted April 14, 2016 Accepted August 22, 2016 by Gloria Arratia 